\title{
IMPLEMENTASI PENDIDIKAN IMAN ANAK MENURUT PERJANJIAN LAMA YANG KONTEKSTUAL DI ERA GLOBALISASI
}

\author{
Oleh: \\ Afrilia Agus Pama'tan \\ Institut Agama Kristen Negeri Toraja \\ Jalan Poros Makale Makassar KM 11,5 Buntu Tangti, Mengkendek, \\ Kabupaten Tana Toraja, Sulawesi Selatan 91871 \\ Email: afriliaaguspamatan@gmail.com
}

\begin{abstract}
ABSTRAK
Iman tidak dapat diukur dengan tolak ukur, iman dapat berubah-ubah sesuai dengan lingkungan yang dialaimi seseorang bila seseorang tersebut tidak memiliki iman yang kokoh. Untuk itu agar iman dapat kokoh dan bertumbuh di dalam Tuhan maka dibutuhkan seseorang atau kelompok yang dapat menolong dalam menjaga iman tersebut. Peran orang tua sebagai orang terdekat bagi anak sangat penting dalam pendidikan iman, bahkan peran guru juga sangat penting dalam penanaman iman yang benar.
\end{abstract}

\section{PENDAHULUAN}

Globalisasi merupakan proses yang memberi pengaruh dalam perubahan dunia baik dalam bidang politik, budaya, agama dan hal-hal lain yang sedang dan akan berlangsung, serta memberi kesadaran bahwa dunia akan terus berkembang ${ }^{1}$. Tidak dapat dibantah bahwa dunia akan mengalami sebuah perkembangan yang terus-menerus. Untuk itu, setiap orang maupun kelompok harus siap dengan berbagai perkembangan dunia tersebut. Menghadapi perkembangan zaman kita harus memiliki bekal yang cukup baik dalam hal pengetahuan maupun iman kita. tidak dapat dipungkiri perkembangan zaman memiliki dampak positif dan juga memiliki dampak yang negatif. Dampak positif dari globalisasi akan mendorong kita untuk berpikir bahwa dunia ini luas untuk itu manusia yang ada di dalam dunia harus memiliki wawasan yang luas tentang dunia, perkembangan teknologi, perkembangan sumber daya manusia maupun sumber daya alam. Sehingga kita yang hidup dalam era globalisasi dapat berkembang dengan baik sesuai

\footnotetext{
${ }^{1}$ Aim Abdulkarim, Pendidikan Kewarganegaraan:Membangun Warga Negara (Bandung: Grafindo, t.t) 81
} 
dengan tuntutan zaman. Dampak negatif dari perkembangan zaman adalah ada beberapa dari nilai-nilai budaya dan juga nilai-nilai agama yang tidak berpadanan dengan perkembangan zaman sehingga kita yang hidup di era globalisasi harus melihat bahwa perkembangan zaman tidak boleh mematikan nilai-nilai budaya maupun nilai-nilai agama.

Dampak negatif globalisasi yang menghilangkan beberapa nilai-nilai agama baik dalam pertumbuhan iman anak, remaja, pemuda, maupun orang tua. Untuk itu perkembangan zaman harus dilihat dalam hal yang positif yang dapat meningkatkan nilai-nilai beriman seseorang, bukan menurunkan bahkan menghilangkan. Mengikuti perkembangan zaman adalah keharusan agar kita selalu update tentang perkembangan dunia, namun harus juga disertai dengan landasan iman yang kuat sehingga perkembangan zaman beriringan dengan pertumbuhan iman. Mulai dari anak-anak dikarenakan usia anak yang mudah terpengaruh dengan lingkungan untuk itu dalam menghadapi perkembangan zaman pendidikan iman harus diterapkan dengan baik bagi anak. Pentingnya pendidikan bagi kelangsungan hidup manusia, untuk terus belajar yang merupakan aktivitas yang dikerjakan sepanjang hayat. Pendidikan terus mengalami perkembangan, namun untuk mengetahui asal muasal pendidikan maka akan membawa kita kembali ke zaman kuno, khususnya era orang Israel kuno pada zaman Alkitab².

Pendidikan iman menurut perjanjian lama yang kontekstual di era globalisasi ini diharapkan dapat memberikan dampak yang baik bagi pertumbuhan iman. Sifat anak yang mudah terpengaruh dengan lingkungan baik lingkungan yang baik maupun yang buruk. Pengaruh lingkungan yang buruk dapat diantisipasi dengan menerapkan pendidikan iman sehingga iman mereka tidak mudah digoyahkan oleh dampak negatif dari era globalisasi.

Penelitian ini beranjak dari fokus masalah, bagaimana implementasi pendidikan iman anak menurut Perjanjian Lama yang kontekstual di era globalisasi.

\section{TUJUAN}

Penelitian ini bertujuan untuk mengetahui implementasi pendidikan iman anak menurut perjanjian lama yang kontekstual di era globalisasi.

\section{MANFAAT}

Manfaat dari penelitian ini adalah yang pertama, hubungan orang tua dan anak akan terjalin lebih baik dan akrab bertumbuh dalam iman bersama. Kedua, bagi guru dan orang tua

\footnotetext{
${ }^{2}$ Yohanes Krismantyo Susanta, “Tradisi Pendidikan Iman Anak Menurut Perjanjian Lama," Lingua: Jurnal Teologi dan Pendidikan Kristen Kontekstual 2, no 2 (Desember 2019) 139
} 
dapat memiliki komunikasi yang baik untuk pertumbuhan iman anak. Bagi guru, dapat mengembangkan pendidikan iman sesuai dengan tuntutan zaman.

\section{PEMBAHASAN}

\section{Keluarga sebagai Pengajar Utama bagi Anak}

Keluarga merupakan unit yang paling dasar dalam kehidupan manusia. Bagi bangsa Israel kuno mengajarkan anak-anak mulai dari usia dini sangatlah penting. Keluarga sebagai tempat pembentukan karakter, pengajaran akan makna hidup sesuai dengan torah dan anak-anak Israel nantinya akan menjadi harapan keluarga dan bangsa ${ }^{3}$. Ruang lingkup pendidikan agama Yahudi mencakup seluruh kegiatan sehari-hari yang lazim dilakukan dengan tuntunan atau arahan dari orang tua sebagai pelajar seumur hidup bagi anak-anak ${ }^{4}$. Menurut Plato pendidikan mencakup perkembangan manusia secara keutuhan ${ }^{5}$, dalam proses pendidikan anak ditolong untuk mencapai kebahagiaan (eudaimonia) menurut Aristoteles ${ }^{6}$. Setiap hari kita mengalami suatu proses belajar yang menghasilkan suatu perubahan. Perubahan yang dihasilkan dari proses belajar adalah suatu perubahan kearah yang positif yang dapat membangun kita menjadi pribadi yang lebih baik seperti harapan orang tua dan bangsa. Seperti bangsa Yahudi yang menjadi harapan mereka adalah anak-anak mereka dapat bertumbuh menjadi pribadi yang baik, yang megenal Tuhan dan karya-karyaNya bagi bangsa mereka.

Peranan setiap orang tua sangatlah penting sebagai pengajar seumur hidup bagi anakanak. Orang tua menanamkan dalam diri anak bahwa Tuhan Allah yang telah memilih bangsa mereka sebagai bangsa yang terpilih sebagai anugerah dari Tuhan. Mereka mengakui keterbatasan mereka sebagai manusia, karena Allah sendirilah yang berotoritas dalam hidup mereka, karena Allah mengetahui manusia (Mzm 139). Orang Yahudi cenderung bersandar kepada Tuhan yang menyatakan diriNya melalui firmanNya, peristiwa-peristiwa sejarah, dan perbuatan-perbuatan ajaib ${ }^{7}$. Peristiwa-peristiwa sejarah yang telah bangsa Israel alami mulai dari keluar dari tempat penindasan di mesir, perjalanan di padang gurun dan banyak lagi yang Tuhan lakukan bagi bangsa mereka. Sehingga menjadikan bangsa Israel sebagai bangsa yang selalu bersandar kepada Tuhan karena perbuatan Allah yang telah mereka alami. Seorang ayah

\footnotetext{
${ }^{3}$ Ibid, 140

${ }^{4}$ Robert R. Boehlke, Sejarah Perkembangan Pikiran dan Praktek Pendidikan Agama Kristen (Jakarta: BPK Gunung Mulia, 2018) 21

${ }^{5}$ Ibid, 7

${ }^{6}$ Ibid, 9

${ }^{7}$ Ibid, 21
} 
memiliki peran utama dalam mendidik anak bagi bangsa Yahudi, kekuasaan ayah kepada anaknya sangat besar (Ams 13:24), anak harus mengikuti didikan orangtua dan tidak boleh bertindak keras terhadap orangtua (kel 21:15, 17).

Mendidik bukanlah sesuatu yang mudah, dibutuhkan motivasi yang benar, keteladanan, dan menciptakan lingkungan mendidik yang menyenangkan bagi anak sehingga anak dengan mudah mengerti didikan yang diberikan dan dapat melakukannya sesuai dengan harapan orang tua dan bangsa. Motivasi yang benar dibutuhkan dalam mendidik anak dalam hal beriman kepada Tuhan. motivasi yang utama adalah agar iman anak semakin bertumbuh di dalam Tuhan, mengenal Tuhan dengan baik melalui firman dan karya-karyaNya, menananmkan dalam hidup mereka bahwa Tuhan adalah sentral dalam hidup mereka. Memberi keteladan bagi anak-anak sangatlah penting, seorang pendidik harus menunjukkan keteladan yang benar bagi anak-anak sehingga anak dapat melihat bahwa pendidik mereka memiliki kehidupan spiritual yang benar dengan Tuhan sehingga mereka dapat meneladani sikap mereka. Bukan hanya itu hubungan seorang pendidik haruslah juga baik dengan orang-orang yang ada disekitar sebagai ciptaan Tuhan. Tokoh-tokoh dalam kitab perjanjian lama yang memiliki keteladan yang benar dalam pendidikan adalah Abraham dengan misi pendidikan ketaatan kepada perintah Tuhan dan percaya akan janji Tuhan ${ }^{8}$. Ishak dengan taat dan setia kepada Tuhan, ketika Tuhan menampak diridi hadapannya, ia segera mendirikan mezbah Tuhan(Kej 26:25a) ${ }^{9}$. Dalam proses mendidik seorang pendidik menciptakan lingkungan yang menyenangkan sehingga anak dengan mudah mengerti apa yang diajarkan kepada mereka. Pendidikan hendaknya dikontekskan dengan kebutuhan mereka sesuai dengan perkembangan zaman.

\section{Pendidikan Iman Anak Israel dalam Perjanjian Lama yang Kontekstual di Era Globalisasi}

Bagi bangsa Yahudi ada dua tipe pendidikan yaitu, pendidikan pre-exilic yang sebagian dijelaskan dalam kitab Ulangan 6, tradisi Yudaism Ul 6:4 menjadi suatu pengakuan iman yang wajib diucapkan tiap pagi dan malam, pengakuan ini yang disebut syema ${ }^{10}$. Pengakuan ini diajarkan oleh orang tua, dalam kitab Ulangan ini menujukkan pola-pola kehidupan keluarga yang kuat yang mendorong dalam proses pendidikan iman ${ }^{11}$. Pendidikan yang diwariskan kepada anak-anak Israel dalam keluarga yaitu melalui ritual hari-hari raya besar, penceritaan, diskusi,

\footnotetext{
${ }^{8}$ Harianto GP, Teologi PAK (Yogyakarta: Penerbit Andi, 2017) 75

${ }^{9}$ Ibid, 82

${ }^{10}$ Dr. I.J. Cairns, Tafsiran Alkitab Kitab Ulangan (Jakarta: BPK Gunung Mulia, 2003) 132

${ }^{11}$ William Bean Kennedy, Christian Education hrough History (Nshville: Abingdon Press, 1996) 21
} 
Tanya jawab, dan jawaban, seorang anak Yahudi menyerap makna kehidupan dan orientasi tertentu pada kehidupan yang dibagi bersama keluarga dan teman-teman. Pengajaran tersebut dilakukan berulang-ulang melalui komunikasi, pengulangan secara lisan sehingga tertanam dalam hidup anak-anak Israel ${ }^{12}$. Peran keluarga khususnya orang tua sangatlah penting dalam mengajarkan syema, sehingga mereka menanamkan nilai iman kepada Tuhan bahwa Tuhan itu Esa. Hidup mengandalkan Tuhan, dan mengikuti hukum-hukum Taurat Allah.

Memasuki era globalisasi, tidak dapat dipisahkan dengan masa Yahudi, sebab pendidikan mula-mula dari bangsa Yahudi. Bila dikontekskan dengan era globalisasi pendidikan iman anak tidak dapat dipisahkan dengan peran orang tua. Baik zaman Yahudi maupun zaman Globalisasi peran orang tua sangatlah penting, karena orang tua tempat belajar utama bagi anak. Pendidikan iman bagi anak di era Globalisasi ini yaitu bagaimana cara orang tua menerapkan Alkitab sebagai sumber untuk mengenal Tuhan, dalam menghadapi perkembangan zaman yang kadang bertolak belakang dengan iman Kristen bahkan nilai-nilai agama Kristen maka pendidikan iman Kristen yang benar dalam konteks era globalisasi penting diajarkan kepada anak. Pendidikan iman tersebut hendaknya dilakukan orang tua dengan terus-menerus sehingga anak selalu mengingatnya.

Pendidikan Yahudi yang kedua yaitu post-exilic atau periode sesudah pembuangan, pada masa setelah masa pembuangan adalah masa gangguan di mana terjadi gannguan terhadap pola kehidupan keluarga yang dulunya stabil kini menjadi tidak stabi ${ }^{13} 1$. Keadaan yang tidak stabil tersebut harus diperbaharui, pendidikan iman kepada anak juga harus diperbaharui oleh karena itu pendidikan dalam periode kedua ini selain peran orang tua peran sinagoge juga diberlakukan untuk mengajarkan iman kepada anak-anak. Pengajaran yang diberikan orang tua tetap berlaku namun, bagi anak laki-laki didirikan sekolah oleh para rabi yang mengajar bahasa Ibrani, tradisi lisan, apa yang dipelajari sebelumnya di rumah kini dipelajari secara formal.

Era globalisasi yang terus berkembang memacu perkembangan pendidikan baik formal maupun informal. Era globalisasi ini menuntut pendidikan iman yang berkembang juga, bukan hanya peran orang tua di rumah mengajarkan iman, namun peran guru disekolah juga dibuuhkan. Agar pendidikan iman dapat berjalan dengan baik maka perlu keterlibatan hubungan yang baik antara orang tua dan guru dalam mengkomunikasikan pendidikan iman anak. Pendidikan iman di

\footnotetext{
${ }^{12}$ Hope S. Antone, Pendidikan Kristiani Kontekstual (Jakarta: BPK Gunung Mulia, 2015) 18

${ }^{13}$ Ibid, 18
} 
sekolah tidak lepas juga dalam tindakan hubungannya dengan orang-orang yang ada disekitar. Bagaimana iman diwujudkan dalam tindakan saling mengasihi baik kepada Guru atau pun teman disekolah.

\section{KESIMPULAN DAN SARAN}

Kesimpulan dari penelitian ini adalah Pendidikan iman konteks bangsa Israel merupakan pendidikan utama yang dilakukan oleh orang tua dalam menanamkan dalam diri anak bahwa Tuhan itu Esa dan Tuhan tahu setiap seluk beluk manusia dan juga harus selalu bersandar kepada Tuhan sebagai pengharapan satu-satunya. Tidak hanya sampai disitu, pendidikan iman harus dilakukan oleh guru di sekolah-sekolah formal dalam menanamkn nilai karakter dan juga nilainilai keterampilan. Berangkat dari konteks Israel maka pendidikan di era globalisasi terus berkembang, namun pendidikan pada konteks Israel masih dapat direlevansikan dalam era globalisasi dimana orang tua dan juga guru berperan aktif dalam pertumbuhan iman anak.

Saran dari penelitian ini adalah, dalam pendidikan iman sangat dibutuhkan kerja sama yang baik antara orang tua dan juga guru disekolah dalam menunjang pendidikan iman yang benar bagi anak. 


\section{DAFTAR PUSTAKA}

Abdulkarim, Aim. t.t. Pendidikan Kewarganegaraan:Membangun Warga Negara. Bandung: Grafindo. Antone, Hope S. 2015. Pendidikan Kristiani Kontekstual. Jakarta: BPK Gunung Mulia.

Boehlke, Robert R. 2018. Sejarah Perkembangan Pikiran dan Praktek Pendidikan Agama Kristen. Jakarta: BPK Gunung Mulia.

Cairms, Dr. I.J. 2003. Tafsiran Alkitab Kitab Ulangan. Jakarta: BPK Gunung Mulia.

GP, Harianto. 2017. Teologi PAK. Yogyakarta: Penerbit ANDI.

Kennedy, William Bean. 1996.Christian Education hrough History. Nshville: Abingdon Press.

Susanta, Yohanes Krismantyo. Tradisi Pendidikan Iman Anak Menurut Perjanjian Lama, Lingua: Jurnal Teologi dan Pendidikan Kristen Kontekstual 2, no 2 Desember 2019. 